\title{
NEW INACTIVATED VACCINE AGAINST ENZOOTIC ENCEPHALOMYELITIS OF SWINES
}

\author{
Derevianko S. V., Soroka V. I., Bowa T. O. \\ Institute of Agricultural Microbiology and Agricultural Production NAAS, \\ 97, Shevchenko Str., Chernihiv, 14027, Ukraine \\ E-mail: biopreparat@mail.ru
}

A specific inactivated vaccine for prevention of enzootic encephalomyelitis (Teschen disease) of swines was created. The vaccine is produced on the basis of "Dniprovskiy-34» strain of Porcine teschovirus-1 isolated in the Ukraine and adjuvant of ASRIAP. During vaccines production the original method of teshoviruses inactivation was used. A single vaccine dose of 2 cubic cm promotes specific swines immunity to Teschen disease remaining for 11 months. Protective antibody levels were observed on the $7^{\text {th }}$ day after vaccination. The maximum level of virus neutralizing antibodies in the blood of vaccinated animals on $60^{\text {th }}$ day have reached 1:8192. Geometric mean titer of antibodies is 1:512, which protects the vaccinated piglets even at intracerebral introduction of 10 lethal doses of control epizootic highly virulent strain of Teschen disease of swines "Chernihivskiy-2372».

A high level of innovative product design was confirmed by commission tests conducted in cooperation with State Scientific Control Institute of Biotechnology and Microorganism Strains and protected with three patents of Ukraine for inventions and useful models. A normative product documentation (Technical Requirements of Ukraine, instructions for production and control and product insert) was created.

Performed feasibility study of the "Teshovak» vaccine allows recommending it into the production and introduction into the practices of veterinary medicine.

Keywords: vaccine, Teschen disease of swines.

Despite of the rapid pace of globalization in world economy, the current trends for realization of national development strategies in advanced countries are aimed on the reduction of domestic production dependence on import and increase of export potential. First of all, this is performed in order to prevent crisis phenomena, increasing number of work places, promoting new higher standards of living and nutrition improvement. Population provision with meat and meat products has been and remains an important problem in agricultural production. In total meat production pork plays a significant role due to precocity, multiple pregnancy and great slaughter weight of animals and is traditional on the Ukrainian market. Therefore, stabilization and further development of the swine industry is necessary.

Enzootic encephalomyelitis (Teschen disease) of swines is one of the most dangerous infectious diseases of swines and can cause significant economic losses in swine industry. The etiological factor of this disease is Porcine teschovirus-1. The effectiveness of the effort against the disease depends on the timely implementation of an anti-epizootic measures, and particularly on the quality of vaccine preparations.

Ukraine is rapidly increasing the scale of application of immunological veterinary medicinal preparations, but existing domestic and foreign means for specific prevention of Teschen disease $[1,2]$ cannot satisfy pork producers for several reasons: antigenic discrepancy of production strains isolated in the early $70 \mathrm{~s}$ of last 
century to epizootic [3], high reactogenicity of vaccines, lack of intensity of postvaccination immunity, multiple input, high products viscosity, etc. As a result of epizootic monitoring the low reactivity of swines vaccinated against Teschen disease was established, indicating a lack of immunogenicity of existing vaccines and the need for continuous monitoring of the intensity of post-vaccination immunity in farms and need of additional financial costs.

With this in mind, the goal of given study was to create an up-to-date domestic inactivated vaccine against the enzootic encephalomyelitis of swines - «Teshovak».

Materials and methods. Epizootic, standard, reference and production strains of virus of Porcine teschovirus-1 species «Dniprvskiy-32», "Dniprvskiy-33», " Dniprvskiy-34», «Gorodnyanskiy-31», «Perechynskiy-642», «Chernihivskiy- 2372 «, Talfan, Teschen 199 and Tirol from the collection of the Institute of Agricultural Microbiology and Agricultural Production of UAAS together with hyperimmune rabbit serum to these strains obtained using own modified scheme were used in the experiments [7].

Studies were performed on passaging cell cultures of embryonic swine kidney lines (SNEV), kidneys of newborn Syrian hamster (BHK-21), passaging cells of piglets testicles (TAP) and kidneys (PK-15). Culture media 199, Ihla, 0.5\% solution of albumin hydrolyzate lactate and cattle serum were used for maintenance of cell cultures.

Virus titer was determined by serial dilutions of cell cultures and calculated by Reed L.J. and Muench H. method [8].

The antigenic relationship of virus strains were established in cross-reaction of neutralization of virus in cell culture at $100 \mathrm{TCD}_{50}$ of viral antigen and 10 neutralizing doses of hyperimmune blood sera [9]. Determination of antibody titer in serum of experimental animals was carried out by neutralization reaction at 100 $\mathrm{TCD}_{50}$ of virus and serial two-time dilutions of blood serum in accordance to developed guidelines [10].

Virus inactivation was performed in accordance to our ethyleneimine technology [5].

In production of experimental models of vaccine adjuvants of ASRIAP (Russian Federation) [11] and ISA 25 (France) were used. Four experimental samples of inactivated vaccine against the Teschen disease of swines were produced: sample 1 - strain «Dniprovskiy-34» with ISA 25 adjuvant, sample 2 - strain «Dniprovskiy-34» with adjuvant ASRIAP, sample 3 - strain «Gorodnyanskiy-31» with ISA 25 adjuvant, sample 4 - strain «Gorodnyanskiy-31» with adjuvant ASRIAP. Adjuvants were mixed with virus containing raw materials at 1:1 ratio, allowing to obtain an emulsion of «water in oil» type, which is more easily packaged and introduced to animals.

The study of antigenic properties of four experimental samples of inactivated vaccine against Teschen disease of swines was performed on piglets of 2 months old. Piglets were inoculated in doses of 2 cubic $\mathrm{cm}$. Observation period -5 months.

Commission trials in cooperation with State Scientific Control Institute of Biotechnology and Microorganism Strains of experimental sample of inactivated vaccine Teschen based on the «Dniprovskiy-34' strain and adjuvant ASRIAP were performed on animals in the vivarium of the Institute of Agricultural Microbiology and Agricultural Production NAAS. 
Harmlessness, immunogenicity and specificity of an inactivated vaccine was determined on piglets of 3.5 months old. Animals of group I were introduced intramuscularly with 1 dose of vaccine $(2$ cubic $\mathrm{cm}$ ). Animals of group II were not vaccinated. After 30 days the animals of groups I and II were intracerebrally infected with virulent epizootic strains of the Teschen virus «Chernihivskiy-2372» at a dose of 0.05 cubic $\mathrm{cm}\left(10 \mathrm{LD}_{50}\right)$ with a titer of $4,5 \mathrm{lg} \mathrm{TCD}_{50} /$ cubic $\mathrm{cm}$. The clinical observations were conducted daily by measurement of body temperature for 50 days.

To determine the harmlessness and areactogenicity the double dose of vaccine (4 cubic $\mathrm{cm}$ ) was injected intramuscularly to piglets 3.5 months old. Observation period -14 days.

Experiments on establishing the shelf life of vaccine were performed with rabbits. Animals of group I were injected intramuscularly with single dose (2 cubic $\mathrm{cm}$ ) of vaccine, that was stored for 12 months at a temperature of $2-8{ }^{\circ} \mathrm{C}$. Animals of group II have received freshly made vaccine. The dynamics of virus neutralization antibodies formation in the blood serum was observed.

Vaccine implementation system was tested in the PJSC «Snov» (Chernigov region) on newborn piglets from vaccinated sows and piglets of different age groups.

Determination of vaccine the cost-effectiveness was performed using the guidelines developed by the Institute of Agricultural Microbiology and Agricultural Production NAAS [12].

Results and discussions. Strains of teshoviruses of swines «Dniprovskiy-32», «Dniprovskiy-33», «Dniprovskiy-34», «Gorodnyanskiy-31» were isolated as a result of virological monitoring on the territory of Ukraine. Based on the analysis for antigenic affinity and differences for experimental vaccine batches «Dniprovskiy-34» and «Gorodnyanskiy-31» strains were selected. It was found that «Dniprovskiy-34» strain is antigenically related to the reference strains Porcine teschovirus-1 Talfan, Teschen 199 and Tirol, epizootic control strain «Chernihivskiy-2372» at 100\% and vaccine strain «Perechynskiy-642» of enzootic encephalomyelitis virus (Teschen disease ) of swines by $67 \%$. Antigenic affinity of «Gorodnyanskiy-31» strain with epizootic, production and reference strains was within the range from 73 to $100 \%$.

Based on selected perspective teshoviruses strains «Dniprovskiy-34» and «Gorodnyanskiy-31» and two adjuvants four experimental samples of inactivated vaccine against teshovirus encephalomyelitis of swines were produced and used in the piglets study.

As the experiment results the immunogenic properties of four experimental samples of inactivated vaccine were studied (Fig. 1). The maximum level of antibodies in the blood of vaccinated animals (1:8192) was observed in variants with sample \#2, based on «Dniprovskiy-34» strain with the infectious activity of $8,2 \mathrm{lg}$ $\mathrm{TCD}_{50} /$ cubic $\mathrm{cm}$ and adjuvant ASRIAP. Geometric mean titer of virus neutralizing antibodies in response to its introduction for the entire period of the experiment was 1:588. At introduction of the sample \#1 of the same strain and ISA 25 adjuvant the largest titer was 1:512 with the average level of antibodies - 1:84. For sample \#3 and \#4 based on «Gorodnyanskiy-31» strain with an infectious activity of 7,5 $\lg \mathrm{TCD}_{50} /$ cubic $\mathrm{cm}$ and ISA 25 adjuvant and ASRIAP the numbers were 1:52 and 1:128 and 1:512 and 1:64, respectively. The protective level of virus neutralizing antibodies 
upon introduction of sample \#2 was formed in 14 days, while for the other vaccination vaccine samples - 21-30 days.

At this the postvaccination virus neutralizing antibodies have persisted in the serum blood of immunized animals with titer 1:128-1:2048 for 6 months. Antibody titers have remained above the protective level during the next 5 months of observation.

Thus, the sample \#2, based on «Dniprovskiy-34» strain and adjuvant ASRIAP appear to be the most promising and was selected for further studies.

Selected experimental sample of inactivated vaccine against the Teschen disease of swines was put into the commission trials. It was established that given vaccine is harmless and non-reactogenic. Piglets that received double dose of vaccine intramuscularly (4 cubic cm), within the 14-days observation were clinically healthy, without tissue inflammation at the injection site, clinical complications or adverse effects on body weight increase (Table 1).

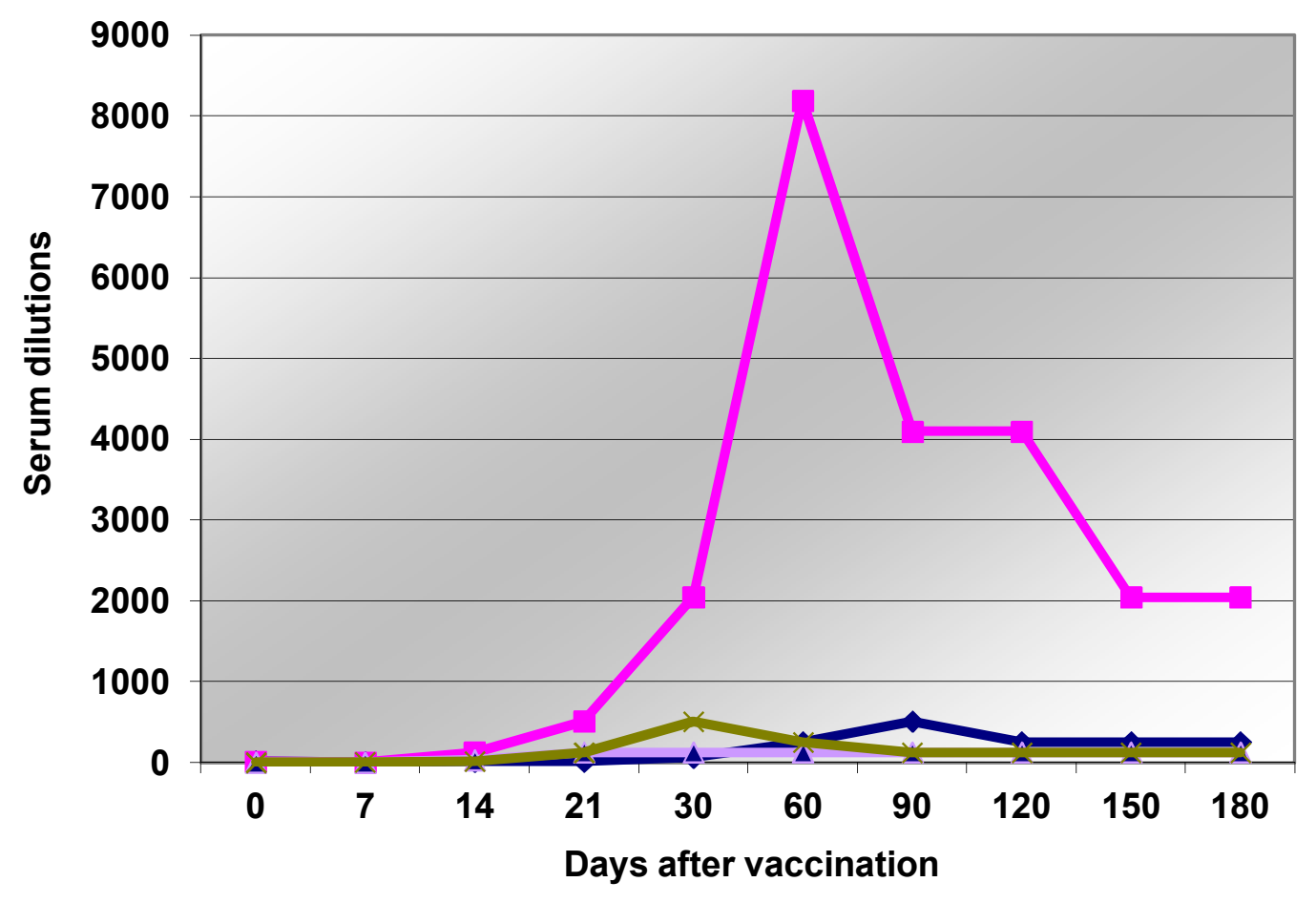

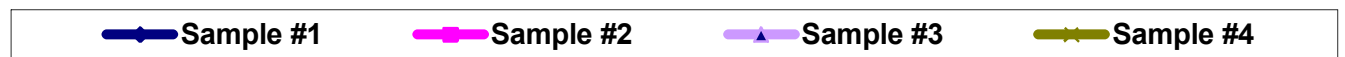

FIGURE 1. Dynamics of the immune response in swines vaccinated with the experimental samples of inactivated vaccine against the Teschen disease of swines.

Sample \#1 - strain «Dniprovskiy-34» with ISA 25 adjuvant, sample \#2 - strain «Dniprovskiy-34» with ASRIAP adjuvant, sample \#3 - strain «Gorodnyanskiy-31» with ISA 25 adjuvant, sample \#4 - strain «Gorodnyanskiy-31» with ASRIAP adjuvant.

The protective level of virus neutralizing antibodies in piglets (1:64 or higher) was observed within 7 days after vaccination. Geometric mean titer at this was 1:104. Maximum antibody levels were observed in 21-28 days. Their geometric mean titer was 1:1024. Individual characteristics of piglet organisms have not significantly affect the formation of immune responses. After 28 days the level of antibodies in animals was 1:1024 with geometric mean titer increased to 1:512. 
TABLE 1. Harmlessness and non-reactogenicity of experimental sample of inactivated vaccine against Teschen disease of swines based on the «Dniprovskiy-34» strain

\begin{tabular}{|c|c|c|c|c|c|c|c|}
\hline \multirow[b]{2}{*}{$\begin{array}{l}\text { Group of } \\
\text { animals }\end{array}$} & \multirow[b]{2}{*}{$\begin{array}{l}\text { № of } \\
\text { piglets }\end{array}$} & \multicolumn{2}{|c|}{ live weight, $\mathrm{kg}$} & \multicolumn{2}{|c|}{$\begin{array}{l}\text { Increase of live } \\
\text { weight, } \mathrm{kg}\end{array}$} & \multicolumn{2}{|c|}{$\begin{array}{l}\text { Daily increase, } \\
\text { mean, g }\end{array}$} \\
\hline & & $\begin{array}{c}\text { Before the } \\
\text { experi- } \\
\text { ment }\end{array}$ & $\begin{array}{l}\text { After } \\
\text { the } \\
\text { experi- } \\
\text { ment }\end{array}$ & $\begin{array}{l}\text { By each } \\
\text { animal }\end{array}$ & $\begin{array}{l}\text { By } \\
\text { group }\end{array}$ & $\begin{array}{c}\text { By each } \\
\text { animal }\end{array}$ & $\begin{array}{l}\text { By } \\
\text { group }\end{array}$ \\
\hline \multirow{3}{*}{$\begin{array}{l}\text { I } \\
\text { (experim } \\
\text { ental) }\end{array}$} & 1 & 19,0 & 23,0 & 4,0 & \multirow{3}{*}{11,5} & 285,7 & \multirow{3}{*}{273,8} \\
\hline & 2 & 17,5 & 22,0 & 4,5 & & 321,4 & \\
\hline & 3 & 14,0 & 17,0 & 3,0 & & 214,3 & \\
\hline \multirow{3}{*}{$\begin{array}{l}\text { II } \\
\text { (control) }\end{array}$} & 4 & 13,5 & 17,0 & 3,5 & \multirow{3}{*}{10,0} & 250,0 & \multirow{3}{*}{238,1} \\
\hline & 5 & 16,5 & 21,0 & 4,5 & & 285,7 & \\
\hline & 7 & 12,0 & 14,0 & 2,0 & & 142,9 & \\
\hline
\end{tabular}

The antigenic activity of given samples of inactivated vaccine on piglets was established (Table 2).

Results of immunogenicity study of experimental sample of inactivated vaccine against Teschen disease of swines are presented in Table 3.

TABLE 2. Antigenic activity of the experimental sample of inactivated vaccine against Teschen disease of swines based on «Dniprovskiy-34» strain

\begin{tabular}{|l|c|c|c|c|c|c|}
\hline \multirow{2}{*}{ №oo Piglets } & \multicolumn{5}{|c|}{ Antibody titers* per day } & \multirow{2}{*}{$\begin{array}{c}\text { Geometric mean } \\
\text { titer }\end{array}$} \\
\cline { 2 - 6 } & 0 & 7 & 14 & 21 & 28 & 256 \\
\hline 6 & 4 & 64 & 256 & 512 & 1024 & 512 \\
\hline 8 & 0 & 128 & 512 & 1024 & 1024 & 512 \\
\hline 9 & 2 & 128 & 256 & 2048 & 1024 & \\
\hline Geometric mean titer & 2 & 104 & 341 & 1024 & 1024 & \\
\hline
\end{tabular}

Note. ${ }^{*}$ - Antibody titers are in the reciprocal values.

TABLE 3. Immunogenic activity of the experimental sample of inactivated vaccine against Teschen disease of swines, based on «Dniprovskiy-34» strain

\begin{tabular}{|l|c|c|c|}
\hline \multicolumn{1}{|c|}{ Group of animals } & №№ animal & \multicolumn{2}{|c|}{$\begin{array}{l}\text { Infection results } \\
\text { sick/dead (days) }\end{array}$} \\
\hline \multirow{3}{*}{ I (experimental) } & 6 & \multicolumn{2}{|c|}{ Clinically healthy } \\
\cline { 2 - 3 } & 8 & \multicolumn{2}{|c|}{} \\
\hline \multirow{2}{*}{ II (control) } & 9 & 11 & 14 \\
\cline { 2 - 4 } & 4 & 23 & 26 \\
\hline
\end{tabular}


After 30 days animals of the group I that were vaccinated intramuscularly with the single dose of 2 cubic $\mathrm{cm}$ and animals of the group II (without vaccination) were intracerebrally infected with epizootic control strain «Chernihivskiy-2372» of Teschen disease virus. Observation results have shown that vaccinated piglets remained clinically healthy throughout the observation period (50 days). Control piglets on $11^{\text {th }}$ and $23^{\text {rd }}$ days got sick with symptoms of Teschen disease: food denial, ohlum-like state, ataxia, tremor of body muscles, shortness of breath, increase of skin sensitiveness, clonic and toxic convulsions, squealing, paresis and paralysis of the limbs. Piglet \#4 have died within 14 days. Piglet \#7 was slaughtered after 26 days after infection. Autopsy have revealed pathological body changes typical for Teschen disease.

Study of vaccine application system have revealed that in blood serum of piglets born from vaccinated sows (identification on the $15^{\text {th }}$ day after piglets) the geometric mean titer of virus neutralizing colostral antibodies were 1:208 (Table 4).

TABLE 4. Antigenic activity of the experimental sample of vaccine against Teschen disease of swines in piglets of different ages

\begin{tabular}{|c|c|c|c|c|c|c|c|c|c|c|c|c|}
\hline & \multicolumn{10}{|c|}{ Geometric mean titers of antibodies* } \\
\cline { 2 - 14 } & \multicolumn{1}{|c|}{$\begin{array}{c}\text { Colostral antibodies, } \\
\text { after/days }\end{array}$} & \multicolumn{10}{|c|}{ after/months } \\
& 0 & 15 & 30 & 45 & 60 & 1 & 2 & 3 & 4 & 5 & 6 & 7 \\
\hline $15-60$ days & - & 208 & 91 & 39 & 14 & - & - & - & - & - & - & - \\
\hline $30-45$ days & - & - & - & - & - & 111 & 91 & 111 & - & - & - & - \\
\hline $3.5-4$ months & - & - & - & - & - & 512 & 676 & 588 & 588 & 676 & 446 & 512 \\
\hline
\end{tabular}

Note. ${ }^{*}-$ Antibody titers are in reciprocal values.

On the 15th day, a gradual decrease of antibodies was noticed. Within the 60 days their level was 1:14. In piglets vaccinated against the Teschen disease prior the 2 months age, the immune response was lower as compared with the ones vaccinated at the age of 3.5-4 months. Swines that were vaccinated in 3.5-4 months age the titer of virus neutralizing antibodies after 7 months have remained at protective levels and were 1:512.

To determine vaccine suitability after 12 months of storage at a temperature of $2-8{ }^{\circ} \mathrm{C}$ rabbits were injected intramuscularly with single dose $(2 \mathrm{cubic} \mathrm{cm})$ of vaccine against Teschen disease. Investigation results of blood serum of rabbits injected with freshly prepared vaccine against Teschen disease and with vaccine after 12 months of storage are depicted in Table 5. In 14 days after introduction of freshly prepared vaccine the titers of antibodies in the blood serum of rabbits were 1:256-1:512. After 12 months of storage vaccine have stimulated immune response at 1:128-1:256. At $21^{\text {st }}$ day, the immune response of rabbits to vaccination was almost leveled. Virus neutralizing titers of antibodies in the blood serum of rabbits 28 days after vaccine introduction of freshly prepared and stored for 12 months vaccines were respectively $1: 1024-1: 2048$ and $1: 128-1: 512$. 
The results obtained, have shown that after the 12 months of storage at $2-8{ }^{\circ} \mathrm{C}$ the experimental sample of inactivated vaccines against the Teschen disease was active and utilizable.

Based on these data the normative product documentation (Technical Requirements of Ukraine, instructions for production and control and product insert) for vaccine was created.

TABLE 4. Antigenic activity of the experimental sample of vaccine against Teschen disease of swines freshly made (C) and after 12 months of storage (S)

\begin{tabular}{|c|c|c|c|c|c|c|c|c|}
\hline \multirow{3}{*}{$\begin{array}{l}\text { №№ } \\
\text { rabbits }\end{array}$} & \multicolumn{6}{|c|}{ Titers of virus neutralizing antibodies* after/days } & \multirow{2}{*}{\multicolumn{2}{|c|}{$\begin{array}{c}\text { Geometric mean titers } \\
\text { of antibodies }\end{array}$}} \\
\hline & \multicolumn{2}{|c|}{14} & \multicolumn{2}{|c|}{21} & \multicolumn{2}{|c|}{28} & & \\
\hline & $\mathrm{C}$ & $\mathrm{S}$ & $\mathrm{C}$ & $\mathrm{S}$ & C & $\mathrm{S}$ & $\mathrm{C}$ & $\mathrm{S}$ \\
\hline 1,2 & 512 & 256 & 256 & 512 & 2048 & 512 & 630 & 388 \\
\hline 3,4 & 256 & 256 & - & 512 & - & 512 & 256 & 388 \\
\hline 5,6 & 256 & 128 & 256 & 128 & 1024 & 128 & 388 & 128 \\
\hline
\end{tabular}

Note. * - Antibody titers are in reciprocal values.

Thereby, a new domestic inactivated vaccine «Teshovak» was created on the basis of highly immunogenic antigenically dominant strain «Dniprovskiy-34» (Porcine teschovirus-1), isolated in Ukraine and deposited in the Depository of State Scientific Control Institute of Biotechnology and Microorganisms Strains (registration number 486) and protected with the patent of Ukraine [4].

During vaccine manufacturing the etylenimin is used for virus inactivation which, unlike formaldehyde, inactivates nucleic acid of the virus without damaging its capsid. This technology provides a high level of virus inactivation in a short period of time, while maintaining the antigenic structure of the capsid inherent to the native virus. Given inactivation method of enzootic encephalomyelitis virus (Teschen disease) of swines is protected by patent of Ukraine for useful model [5].

ASRIAP adjuvant was used for vaccine production [11]. It has a low viscosity and has no problems with vaccines introduction to animals even at low temperatures.

Application of new strain, adjuvant and virus inactivation technology for ensure high innovation level of vaccine. Commission trials of inactivated vaccines against the Teschen disease of swines confirm its reliable consumer characteristics: high specificity, immunogenicity, immunity tension, antigenic activity, avirulence, lack of reactogenicity, ease of use even at low temperatures. Currently this is the only inactivated vaccine against Teschen disease of swines, which ensures such level of immunity tension that allows swines protection against the Teschen disease of swines, even at 10 intracerebral introduction of lethal doses of epizootic control strain. The vaccine provides a high level of colostral antibodies in newborn piglets from vaccinated sows and prolonged immunity tension. Created vaccine has a long shelf life and is protected with the Patent Ukraine for useful model [6].

Combination of the above-mentioned characteristics ensures «Teshovak» vaccine competitiveness in relation to existing domestic and foreign analogues, that is confirmed by expert judgments and economic evaluations. 
The domestic market for veterinary preparations is about 100 million USD, with the immunological part - about $40 \%$ [13]. Swines population in Ukraine is more than 7.5 million. The economic effect (prevented losses) from the vaccine introduction on farms may reach 350 million UAH per year, if vaccinating 1 million of livestock, which is 1000 times larger the cost of its creation. The potential sales volume of inactivated vaccines against the Teschen disease of swines «Teshovak» (under the same conditions) can be up to 3 million UAH per year if seting single dose price to $3 \mathrm{UAH}$.

The introduction of new vaccine into the production should improve the epizootic situation with Teschen disease of swines, enhance development and application of domestic scientific and technological capacity by engaging scientific personnel into the manufacturing process. That will significantly improve the performance of biotechnological production and create more jobs, which, in turn, may have a positive impact on competitiveness of the domestic biotechnological industry, reducing Ukraine's dependence on imports of immunological preparations and promoting export of domestic immunobiological products. 